\title{
PERTANGGUNGJAWABAN NOTARIS PADA PENERBITAN COVERNOTE
}

\author{
Rahmiah Kadir*, Farida Patittingi, Nurfaidah Said, \\ Muhammad Ilham Arisaputra**
}

Prodi Magister Kenotariatan dan Departemen Hukum Keperdataan, Fakultas Hukum Universitas Hasanuddin

Jalan Pintu Dua Unhas No.KM.10, Tamalanrea Indah, Kec. Tamalanrea, Kota Makassar, Sulawesi Selatan 90245

\begin{abstract}
Covernote is a certificate containing the ability of a notary to carry out what the creditor wants. Notary is solely responsible for the content contained in the covernote. In the event of a nonconformity between a statement in covernote and its reality in the field, the notary must be responsible, whether criminal or civil and even morally responsible. A notary's office is a profession that is given great trust and high by society so that what he poured in his legal products or in his explanations can be regarded as something that is true. So, when there is a notary statement that is not in accordance with the actual situation, it will have an impact on tercederainya notary profession itself.
\end{abstract}

Keywords: accountability, covernote, notary.

\section{Intisari}

Covernote adalah surat keterangan yang berisikan kesanggupan dari notaris untuk melaksanakan apa yang diinginkan oleh kreditur. Notaris bertanggung jawab penuh atas isi yang dimuat dalam covernote. Ketidaksesuaian yang terjadi antara pernyataan dalam covernote dengan realitas di lapangan, notaris harus bertanggung jawab, baik secara pidana, perdata, ataupun bertanggung jawab secara moral. Jabatan notaris adalah profesi yang diberikan kepercayaan besar dan tinggi oleh masyarakat sehingga apa yang dituangkannya dalam produk hukumnya ataupun pada keterangan-keterangannya dapat dianggap sebagai sesuatu yang benar. Jadi, ketika terdapat pernyataan notaris yang tidak sesuai dengan keadaan yang sebenarnya, maka akan berdampak pada tercederainya profesi notaris itu sendiri.

Kata Kunci: covernote, notaris, pertanggungjawaban.

\section{Pokok Muatan}

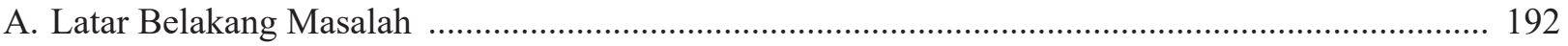

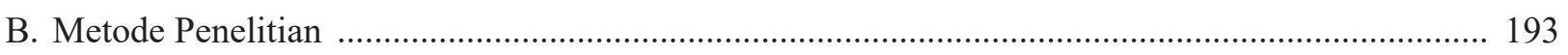

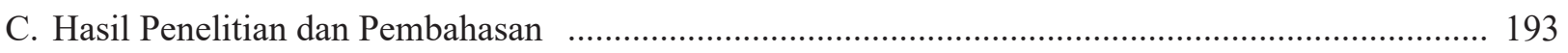

1. Tanggung Jawab Notaris Dalam Menerbitkan Covernote terhadap Pencairan Kredit

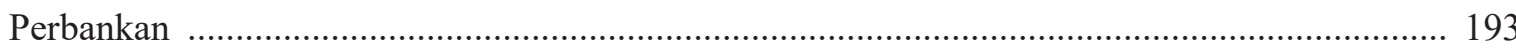

2. Implikasi Hukum terhadap Pencairan Kredit Perbankan Atas Dasar Covernote Notaris ............ 199

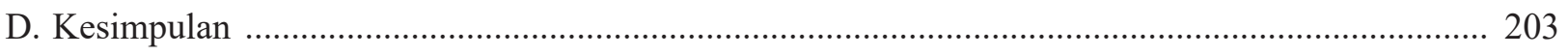

Alamat korespondensi: rahmiahkadir@gmail.com.
Alamat korespondensi: ilhamarisaputra@gmail.com 


\section{A. Latar Belakang Masalah}

Seiring dengan perkembangan perekonomian nasional dewasa ini, maka hubungan hukum antar individu dan lalu lintas hukum dalam kehidupan masyarakat semakin meningkat karena tingkat kesadaran hukum masyarakat semakin membaik, sehingga dalam perkembangannya setiap hubungan hukum dalam masyarakat memerlukan sebuah alat bukti yang sah dan kuat yang pada gilirannya menjadi kebutuhan masyarakat dalam menentukan hak dan kewajiban secara jelas, utamanya bagi seseorang sebagai subjek hukum dalam masyarakat.

Akta autentik sebagai alat bukti yang sempurna mempunyai peranan penting dalam aktifitas lalu lintas hukum maupun setiap hubungan hukum yang terjadi dalam kehidupan masyarakat sehari-hari, misalnya dalam pergaulan lapangan hukum bisnis, kegiatan bidang perbankan, bidang pertanahan, kegiatan sosial dan kegiatan lain di bidang perekonomian pada umumnya sehingga kebutuhan pembuktian tertulis yang berupa akta autentik semakin meningkat. Hal ini sejalan dengan berkembangnya tuntutan adanya kepastian hukum dalam berbagai interaksi dalam bidang ekonomi dan sosial, baik pada tingkat nasional maupun internasional.

Keberadaan alat bukti tertulis berupa akta autentik menentukan secara jelas mengenai hak dan kewajiban seseorang dan menjamin adanya kepastian hukum. Menurut Subekti, bahwa akta autentik adalah suatu akta yang dibuat oleh atau dihadapan seorang pejabat umum yang menurut undang-undang ditugaskan untuk membuat suratsurat akta tersebut, sedangkan akta di bawah tangan ialah tiap akta yang tidak dibuat oleh atau dengan perantara seorang pejabat umum. ${ }^{1}$

Notaris adalah pejabat umum yang melaksanakan sebagian tugas-tugas pemerintahan utamanya dalam lapangan hukum privat. Jabatan Notaris ini di Indonesia diatur dengan UndangUndang Nomor 2 Tahun 2014 tentang Perubahan atas Undang-Undang Nomor 30 Tahun 2004 tentang
Jabatan Notaris (selanjutnya disingkat UUJN).

Kewenangan Notaris diatur secara tegas dan jelas di dalam Pasal 15 UUJN, yaitu Notaris berwenang membuat akta autentik mengenai semua perbuatan, perjanjian dan petetapan yang diharuskan oleh peraturan perundang-undangan dan/atau yang dikehendaki oleh yang berkepentingan untuk dinyatakan dalam akta autentik, menjamin kepastian tanggal pembuatan akta, menyimpan akta, memberikan grosse, salinan dan kutipan akta, semuanya itu sepanjang pembuatan akta itu tidak juga ditugaskan atau dikecualikan kepada pejabat lain atau orang lain yang ditetapkan oleh undangundang.

Berkaitan dengan wewenang notaris dalam membuat akta, tujuan dibuatnya akta tersebut adalah untuk mengikat secara hukum para pihak yang akan melakukan perbuatan hukum. Perkreditan misalnya, akta perjanjian kredit yang dibuat oleh notaris merupakan instrumen yang mengikat kreditur dan debitur. Setelah dibuat dan ditandatangani perjanjian kredit antara kreditur dan debitur, maka biasanya pihak kreditur akan meminta kepada notaris untuk membuat covernote.

Covernote yang dimaksud di sini adalah surat keterangan yang berisikan kesanggupan dari notaris untuk melaksanakan apa yang diinginkan oleh kreditur. Biasanya covernote diterbitkan oleh notaris dalam hal persyaratan formil untuk keperluan pencairan kredit yang diinginkan oleh kreditur belum sepenuhnya dipenuhi oleh debitur. Biasanya terkait dengan agunan yang harus dipastikan terlebih dahulu keabsahan kepemilikannya.

Covernote sebenarnya bukanlah produk hukum notaris sebagaimana ditentukan dalam UUJN. Covernote hanyalah merupakan surat keterangan dari notaris untuk kreditur yang menerangkan bahwa proses-proses yang berkaitan dengan perjanjian kredit antara kreditur dan debitur sementara dalam pengerjaan dari pihak notaris, seperti misalnya pembebanan agunan kredit.

Covernote merupakan surat yang 
menerangkan bahwa adanya proses yang masih berjalan dalam pengurusan akta-akta yang belum selesai. Hal ini biasanya terjadi dalam perjanjian kredit yang mana membutuhkan sertipikat sebagai jaminan, namun sertipikat yang akan dibebankan hak tanggungan tersebut yang menjadi perjanjian ikutan dalam perjanjian kredit tersebut belum dapat dipenuhi yang disebabkan oleh masih dalam proses, misalnya masih perlu dilakukan pengecekan sertipikat, balik nama, atau proses lainnya yang masih sedang berjalan.

Pada praktiknya, Bank akan menyetujui permohonan kredit calon debitor hanya dengan dasar covernote yang diterbitkan oleh notaris. Hal tersebut kemudian menyebabkan terjadinya kerugian bagi bank, yaitu terjadinya kredit macet. Setiap analisis kredit harus dapat dipertanggungjawabkan sesuai dengan peraturan internal bank dan peraturan perundang-undangan yang berlaku. Pelaksanaan perkreditan pada lembaga perbankan harus berdasarkan prinsip kehati-hatian bank sehingga kredit yang disalurkan dapat memberi manfaat kepada masyarakat dan mencegah terjadinya kredit macet.

Tulisan ini ditujukan untuk membahas mengenai kewenangan notaris dalam membuat covernote yang kemudian dijadikan dasar oleh pihak perbankan untuk mencairkan kredit yang dimohonkan oleh debitur. Selanjutnya, akan dikaji pula tanggung jawab notaris dalam penerbitan covernote terhadap pencairan kredit perbankan serta implikasi hukumnya terhadap pencairan kredit perbankan. Berdasarkan uraian pendahuluan di atas, maka menarik untuk dikaji lebih lanjut dengan rumusan masalah sebagai berikut: Pertama, Bagaimanakah tanggung jawab notaris dalam menerbitkan covernote terhadap pencairan kredit perbankan? Kedua, Bagaimanakah implikasi hukum terhadap pencairan kredit perbankan atas dasar covernote Notaris?

\section{B. Metode Penelitian}

Metode penelitian yang digunakan adalah metode penelitian hukum yuridis normatif, yaitu mengkaji peraturan perundang-undangan, teoriteori hukum, dan yurisprudensi yang berhubungan dengan permasalahan yang dibahas. Untuk itu, pendekatan yang digunakan dalam penelitian ini menggunakan pendekatan perundang-undangan (statute approach) dan pendekatan konseptual (conceptual approach). Bahan hukum yang digunakan dalam penelitian ini adalah bahan hukum primer yang terdiri dari peraturan perundangundangan yang terkait dengan isu penelitian, sedangkan bahan hukum sekunder didapatkan dari literatur, majalah, maupun informasi, baik dari media cetak maupun media elektronik yang mendukung penelitian ini. Pengumpulan bahan hukum dilakukan melalui penelusuran pustaka yang diawali dengan inventarisasi, klasifikasi, dan sistematisasi bahan hukum. Bahan-bahan hukum yang telah dikumpulkan dan diinventarisasi kemudian diolah dan dikaji secara mendalam sehingga diperoleh gambaran yang utuh mengenai persoalan hukum yang diteliti. Bahan hukum primer dan sekunder yang telah disinkronisasi secara sistematis kemudian dikaji lebih lanjut berdasarkan teori-teori hukum yang ada sehingga diperoleh rumusan ilmiah untuk menjawab persoalan hukum yang dibahas dalam penelitian ini.

\section{Hasil Penelitian dan Pembahasan \\ 1. Tanggung Jawab Notaris Dalam Menerbit- kan Covernote Terhadap Pencairan Kredit Perbankan}

Berdasarkan Pasal 1 angka 1 UUJN, Notaris didefinisikan sebagai pejabat umum yang berwenang untuk membuat akta otentik dan kewenangan lainnya sebagaimana dimaksud dalam UUJN. ${ }^{2}$ Definisi yang diberikan oleh UUJN ini merujuk pada tugas dan wewenang yang dijalankan oleh notaris. Artinya, notaris memiliki tugas sebagai 
pejabat umum dan memiliki wewenang untuk membuat akta otentik serta kewenangan lainnya yang diatur oleh UUJN.

Kewenangan notaris sendiri dapat dilihat pada Pasal 15 UUJN, yaitu sebagai berikut: ${ }^{3}$

(1) Notaris berwenang membuat Akta autentik mengenai semua perbuatan, perjanjian, dan penetapan, yang diharuskan oleh peraturan perundangundangan dan/atau yang dikehendaki oleh yang berkepentingan untuk dinyatakan dalam Akta autentik, menjamin kepastian tanggal pembuatan Akta, menyimpan Akta, memberikan grosse, salinan dan kutipan Akta, semua itu sepanjang pembuatan Akta itu tidak juga ditugaskan atau dikecualikan kepada pejabat lain atau orang lain yang ditetapkan oleh undangundang.

(2) Selain kewenangan sebagaimana dimaksud pada ayat (1), Notaris berwenang pula:

a. Mengesahkan tanda tangan dan menetapkan kepastian tanggal surat di bawah tangan dengan mendaftar dalam buku khusus;

b. Membukukan surat di bawah tangan dengan mendaftar dalam buku khusus;

c. Membuat kopi dari asli surat di bawah tangan berupa salinan yang memuat uraian sebagaimana ditulis dan digambarkan dalam surat yang bersangkutan;

d. Melakukan pengesahan kecocokan fotokopi dengan surat aslinya;

e. Membuat penyuluhan hukum sehubungan dengan pembuatan Akta;

f. Membuat Akta yang berkaitan dengan pertanahan; atau

g. Membuat Akta risalah lelang.

(3) Selain kewenangan sebagaimana dimaksud pada ayat (1) dan ayat (2), Notaris mempunyai kewenangan lain yang diatur dalam peraturan perundang-undangan.

Seorang pejabat umum sebelum menjalankan jabatannya dengan sah harus terlebih dahulu mengangkat sumpah (di ambil sumpahnya). Selama hal tersebut belum dilakukan, maka jabatan itu tidak boleh atau tidak dapat dijalankan dengan sah. Notaris dalam menjalankan tugas jabatannya harus berdasarkan wewenang yang telah ada pada jabatan. ${ }^{4}$ Pemberian kualifikasi Notaris sebagai Pejabat Umum berkaitan dengan wewenang Notaris. Menurut Wawan Setiawan ${ }^{5}$, Pejabat Umum ialah organ negara yang diperlengkapi dengan kekuasaan umum, berwenang menjalankan sebahagian dari kekuasaan negara untuk membuat alat bukti tertulis dan autentik dalam bidang hukum perdata. Soegondo Notodisoejo ${ }^{6}$ mengatakan bahwa:

Pejabat umum adalah seorang yang diangkat dan diberhentikan oleh pemerintah dan diberi wewenang dan kewajiban untuk melayani publik dalam hal-hal tertentu karena ia ikut serta melaksanakan suatu kekuasaan yang bersumber pada kewibawaan (gezag) dari pemerintah. Dalam jabatannya tersimpul suatu sifat dan ciri khas yang membedakannya dari jabatan-jabatan lainnya dalam masyarakat.

Sebagai seorang pejabat umum, notaris diangkat dan diberhentikan oleh menteri, karena itu pula notaris disebut pejabat umum sekalipun statusnya bukanlah pegawai negeri sebagaimana dimaksud oleh peraturan perundang-undangan di

Pasal 15 Undang-Undang Nomor 2 Tahun 2014 tentang Perubahan atas Undang-Undang Nomor 30 Tahun 2004 tentang Jabatan Notaris (Lembaran Negara Republik Indonesia Tahun 2014 Nomor 3, Tambahan Lembaran Negara Republik Indonesia Nomor 5491).

Habib Adjie, 2012, Bernas-Bernas Pemikiran di Bidang Notaris dan PPAT, Mandar Maju, Bandung, hlm. 13.

Wawan Setiawan, Kedudukan dan Keberadaan Pejabat Umum serta PPAT dibandingkan dengan Kedudukan Pejabat Tata Usaha Negara Menurut Sistem Hukum Nasional, Pengurus Pusat Pejabat Pembuat Akta Tanah, Jakarta, 2 Juli 2011, hlm. 8.

R. Soegondo, 1993, Hukum Notariat di Indonesia Suatu Penjelasan, Raja Grafindo Persada, Jakarta, hlm. 44. 
bidang kepegawaian. Notaris merupakan profesi yang mandiri yang tetap terikat dengan aturan jabatannya dalam menjalankan jabatannya seharihari, akan tetapi notaris tidak menerima gaji dan pensiun dari pemerintah. Pendapatan notaris diperoleh dari honorarium yang ditagihkan kepada kliennya.

Notaris dalam menjalankan jabatannya juga melaksanakan administrasi perkantoran seperti surat menyurat dengan pihak lain. Salah satu bentuk administrasi perkantoran notaris yang sering dijumpai adalah penerbitan covernote, khususnya dalam kredit perbankan. Seperti yang telah dijelaskan sebelumnya bahwa setelah dibuat dan ditandatangani perjanjian kredit antara kreditur dan debitur, maka biasanya pihak kreditur akan meminta kepada notaris untuk membuat covernote. Covernote yang dimaksud di sini adalah surat keterangan yang berisikan kesanggupan dari notaris untuk melaksanakan apa yang diinginkan oleh kreditur. Biasanya covernote diterbitkan oleh notaris dalam hal persyaratan formil untuk keperluan pencairan kredit yang diinginkan oleh kreditur belum sepenuhnya dipenuhi oleh debitur. Biasanya terkait dengan agunan yang harus dipastikan terlebih dahulu keabsahan kepemilikannya.

Covernote berasal dari bahasa inggris yang terdiri dari dua kata yang terpisah, yakni cover dan note, dimana cover berarti tutup dan note berarti tanda catatan. Melihat arti dari kedua kata itu, maka covernote berarti catatan penutup. Istilah dalam kenotariatan, arti dari covernote adalah surat keterangan, yakni surat keterangan yang dikeluarkan oleh seorang notaris yang dipercaya dan diandalkan atas tanda tangan, cap, dan segelnya guna untuk penjamin dan sebagai alat bukti yang kuat. ${ }^{7}$

Covernote adalah surat keterangan yang diberikan oleh Notaris kepada pihak Bank yang berisi keterangan bahwa pada tanggal tertentu telah dilaksanakan penanda-tanganan Akta Perjanjian Kredit dan Akta Pemberian Jaminan antara pihak Debitor dan pihak Bank, serta keterangan lainnya. Menurut Muhaymiyah ${ }^{8}$, Covernote merupakan surat keterangan atau sering diistilahkan sebagai catatan penutup yang dibuat oleh Notaris. Covernote hanya menjadi pegangan sementara bagi bank hingga diserahkannya seluruh akta dan jaminan yang telah didaftarkan melalui jasa notaris/PPAT. Covernote pada umumnya berisi keterangan Notaris antara lain mengenai : a) penyebutan identitas notaris/PPAT dan wilayah kerjanya; b) keterangan mengenai jenis, tanggal dan nomor akta yang dibuat; c) keterangan mengenai pengurusan akta, sertipikat, balik nama atau lain sejenisnya yang masih dalam proses; d) keterangan mengenai jangka waktu penyelesaian proses; e) keterangan mengenai pihak yang berhak menerima apabila proses telah selesai dilakukan; f) tempat dan tanggal pembuatan Covernote, tanda tangan dan stempel notaris.

Covernote dikeluarkan karena adanya pengurusan akta-akta. Covernote tidak diserahkan karena belum lunas utangnya, adanya tunggakan BPHTB (Bea Perolehan Hak Atas Tanah dan Bagunan). Covernote tampaknya dalam praktik mengikat secara moral (moral binding). Dikeluarkannya covernote oleh notaris yang berisikan pernyataan. Pernyataan pada prinsipnya tidak digantungkan pada bentuk tertentu. Pernyataan demikian dapat diberikan secara tegas, namun juga tercakup kedalam satu atau lebih perilaku. Terkecuali ditentukan lain, pernyataan tercakup ke dalam penyampaian keterangan lain, dapat disampaikan dalam bentuk apapun juga atau tercakup dalam satu atau lebih perilaku.

Pada dasarnya covernote muncul sebagai surat keterangan tidak hanya terjadi dalam hukum jaminan berupa sertipikat hak tanggungan, melainkan juga dapat dikeluarkan oleh notaris dalam

Tan Thong Kie, 2000, Buku I Studi Notariat (Serba-Serbi Praktek Notaris), Ichtiar Baru Van Hoeve, Jakarta, hlm. 12. Lihat pula dalam I Dewa Made Dwi Sanjaya, "Tanggung Jawab Hukum Notaris Terhadap Penerbitan Covernote Dalam Pemberian Kredit”, Riau Law Journal, Vol. 1, No. 2, November 2017, hlm. 190.

8 Lihat pendapat Muhaymiyah Tan Kamelo, dkk. dalam Dewi Rachmiyani, et al., "Covernote Notaris Dalam Perjanjian Kredit Dalam Perspektif Hukum Jaminan”, Acta Diurnal (Jurnal Ilmu Hukum Kenotariatan), Vol. 1, No. 1, Desember 2017, hlm. 78. 
akta yang lain seperti gadai, hipotik, fidusia. Namun yang menjadi fokus pembahasan dalam penulisan ini hanya mengkaji hak tanggungan mengingat bahwa rata-rata dalam pencairan kredit oleh bank bagi debitor. Bank lebih senang dan terbiasa mencairkan kredit yang disertai hak tanggungan yang objek jaminannya adalah tanah. Terutama tanah bernilai ekonomi dan harganya tidak pernah turun-turun.

Covernote tersebut dibuat dalam bentuk surat keterangan yang dibuat oleh Notaris sendiri atas suatu tindakan hukum para pihak yang dilakukan oleh para pihak di hadapan Notaris. Covernote ini terkadang menjadi instrument pamungkas untuk menutup semua tindakan hukum tersebut untuk menindak lanjuti tindakan hukum yang lain. Sebaga contoh ketika Perjanjian Kredit yang kemudian dibuatkan SKMHT dan atau APHT karena semuanya telah ditandatangani oleh para pihak dihadapan Notaris meskipun secara administratif kenotarisan belum selesai, maka untuk kepentingan Bank (Pemberi Kredit) dan para pihak (debitor), Notaris akan membuat atau mengeluarkan covernote, yang menyatakan bahwa tindakan hukum para penghadap tersebut telah selesai dilakukan jika Bank telah menerima covernote seperti itu, telah cukup alasan bagi Bank untuk dapat mencairkan ataupun merealisasikan kredit tersebut kepada debitor atau nasabah.

Covernote tersebut dapat dilakukan oleh Notaris dalam segala situasi dan kondisi yang berkaitan dengan pelaksanaan tugas dan jabatan Notaris tersebut. Pasal 15 UUJN tidak menyebutkan bahwa covernote merupakan salah satu wewenang yang dimiliki oleh notaris atau merupakan produk hukum dari Notaris. Covernote pada dasarnya merupakan surat keterangan yang berisikan kesanggupan dari notaris untuk melaksanakan apa yang diinginkan oleh kreditur. Biasanya covernote diterbitkan oleh notaris dalam hal persyaratan formil untuk keperluan pencairan kredit yang diinginkan oleh kreditur belum sepenuhnya dipenuhi oleh debitur. Biasanya terkait dengan agunan yang harus dipastikan terlebih dahulu keabsahan kepemilikannya oleh notaris dan kreditur.
Isi dari covernote itu sendiri pada tataran praktek memuat antara lain (1) identitas Notaris/ PPAT dan wilayah kerjanya; (2) keterangan mengenai jenis, tanggal dan nomor akta yang dibuat; (3) keterangan mengenai pengurusan akta, sertipikat, balik nama atau lain sejenisnya yang masih dalam proses; (4) keterangan mengenai jangka waktu penyelesaian proses; (5) keterangan mengenai pihak yang berhak menerima apabila proses telah selesai dilakukan; dan (6) tempat dan tanggal pembuatan Covernote, tanda tangan dan stempel Notaris. Covernote diterbitkan oleh Notaris sebagai surat keterangan atas suatu tindakan hukum para pihak dan dilakukan dihadapan Notaris. Covernote yang diterbitkan oleh notaris didasarkan atas kepentingan subjek hukum, yakni debitor dan kreditor yang ingin melakukan perjanjian kredit perbankan, yang dalam hal ini objek jaminan milik debitor masih dalam proses hukum sehingga bank bermohon kepada Notaris untuk dibuatkan covernote yang berisikan pernyataan yang di dalamnya menjelaskan proses, progres, dan kendala dari objek jaminan debitor.

Covernote atau pernyataan dari notaris sesungguhnya bukanlah merupakan syarat untuk pencairan kredit oleh karena untuk mencairkan suatu kredit terdapat syarat-syarat yang harus dipenuhi terlebih dahulu, misalnya objek jaminan telah dibebankan hak tanggungan atau fidusia. Pembebanan atas barang jaminan harus dilaksanakan oleh debitor dengan bantuan dari Notaris. Bantuan tersebut didasarkan atas suatu perbuatan hukum yang memerlukan waktu karena adanya suatu proses hukum dan disinilah peran covernote dari notaris yang menjelaskan bahwa perbuatan hukum tersebut sudah dijalankan oleh debitor sesuai dengan aturan yang berlaku.

Dalam proses hal ini akan menjadi pertimbangan dan memberikan keyakinan kepada pihak bank bahwa pencairan kredit dapat dilakukan karena syarat-syarat pencairan kredit telah dilaksankan atau sudah dalam proses. Covernote juga berfungsi sebagai jaminan kelengkapan berkas yang belum terlengkapi dalam sebuah permohonan di instansi. 
Oleh karena itu, covernote atau pernyataan notaris harus lengkap, transparan, dan informatif dan disertai dengan lampiran-lampiran yang menunjang isi dari covernote itu sendiri.

Pembuatan covernote yang dilakukan oleh Notaris memiliki peran yang sangat penting dalam kredit perbankan. Hal ini terjadi karena yang akan dijaminkan oleh debitor untuk mendapatkan kredit masih dalam proses hukum, sehingga dengan adanya keberadaan covernote tersebut dapat memberikan tambahan keyakinan kepada bank untuk melakukan pencairan dana kredit. Melihat pentingnya peran covernote ini menjadikan dalam proses pembuatan covernote tidak bisa dilakukan dengan serta merta saja, namun notaris harus melakukan pengecekan terlebih dahulu kepada intansi terkait apakah memang keterangan yang disampaikan oleh debitor memang benar adanya.

Secara yuridis, pengaturan mengenai kewenangan Notaris menerbitkan covernote tidak diatur dalam peraturan perundang-undangan. Perbuatan Notaris dalam menerbitkan covernote hanya merupakan kebiasaan yang dilakukan oleh notaris dalam praktik kenotariatan. Covernote dapat digolongkan mempunyai sumber dari sumber hukum formil, yaitu berdasarkan kebiasaan dimana kebiasaan merupakan perbuatan manusia yang dilakukan secara tetap dan berulang-ulang dalam waktu tertentu.

Menurut Kansil, apabila suatu kebiasaan tertentu diterima oleh masyarakat, dan kebiasaan itu secara berulang-ulang dilakukan sedemikian rupa sehingga tindakan yang berlawanan dengan kebiasaan itu dirasakan sebagai pelanggaran perasaan hukum, maka demikian timbullah suatu kebiasaan hukum yang oleh pergaulan dipandang sebagai hukum9. Menurut penulis, covernote hanyalah merupakan perbuatan administrasi biasa yang dilakukan oleh Notaris selayaknya surat menyurat biasa.

Covernote hanyalah layaknya persuratan biasa yang diterbitkan atau dikeluarkan oleh suatu instansi atau lembaga yang menerangkan suatu hal berkaitan dengan pelaksanaan fungsifungsinya. Jadi, covernote bukanlah suatu akta (baik akta autentik ataupun akta di bawah tangan) yang merupakan produk hukum notaris dalam melaksanakan fungsinya sebagaimana diatur dalam UUJN, melainkan hanya merupakan surat keterangan sebagai pejabat publik kepada instansi atau lembaga tertentu yang isinya menerangkan pelaksanaan wewenang dan fungsinya.

Melihat penerbitan covernote oleh notaris dapat dipandang sebagai suatu kebiasaan, maka tentunya dapat diukur keberlakukan dan daya mengikat dari covernote tersebut oleh sebab pelaksanaan penerbitan covernote oleh notaris dapat digolongkan sebagai hukum kebiasaan. Menurut pandangan Brugginnk ${ }^{10}$, ada tiga faktor yang menjadi parameter sebuah produk hukum dapat berlaku secara baik, yakni mempunyai dasar keberlakuan yuridis, sosiologis, dan filosofis. Keberlakuan yuridis atau normatif suatu peraturan atau kaidah jika kaidah itu merupakan bagian dari suatu kaidah hukum tertentu yang di dalam kaidahkaidah hukum tersebut saling menunjuk yang satu terhadap yang lain. Sistem kaidah hukum yang demikian terdiri atas suatu keseluruhan hierarki kaidah hukum khusus yang bertumpu pada kaidah hukum umum.

Kaidah hukum khusus yang lebih rendah diderivasi dari kaidah hukum yang lebih tinggi. Sementara itu, keberlakuan empiris/sosiologis berhubungan dengan situasi ketika para warga masyarakat mematuhi hukum di mana hukum itu diberlakukan. Keberlakuan filosofis/evaluatif berkaitan dengan keharusan peraturan hukum mencerminkan sistem nilai, baik sebagai sarana yang melindungi nilai-nilai maupun sebagai sarana mewujudkannya dalam tingkah laku masyarakat.

Dikaitkan dengan pendapat Bruggink di atas, penerbitan covernote oleh notaris dapat digolongkan 
ke dalam keberlakukan empiris/sosiologis oleh karena dilakukan secara terus menerus dan secara tetap oleh masyarakat maupun notaris dan lembaga atau instansi yang terkait serta diterima keberadaannya dalam masyarakat. Demikian, maka penerbitan covernote memiliki daya mengikat yang selayaknya pembuatan perjanjian. Daya mengikat covernote menurut penulis hanyalah mengikat para pihaknya saja, yakni kreditor, debitor, dan notaris. Selain itu, daya mengikat covernote akan mengikat pula pihak ketiga yang terkait dengan perbuatan hukum yang dilakukan oleh kreditor dan debitor. Posisi notaris dalam konteks ini adalah sebagai pejabat yang menerbitkan covernote sehingga isi dari covernote memiliki daya mengikat terhadap notaris itu sendiri. Kekuatan mengikatnya covernote hanya dapat diukur dari eksistensi covernote sebagai jaminan bagi Bank bahwa dokumen-dokumen yang dibutuhkan untuk pencairan kredit dalam pengurusan notaris. Jadi, kedudukan covernote dalam konteks ini bukan sebagai bukti agunan, namun hanya penegasan bahwa agunan dalam proses pengurusan.

Ketika bank telah mempunyai surat persetujuan terhadap permohonan kredit seorang debitor, maka bank itu berkewajiban untuk mengumpulkan dokumen-dokumen terkait objek pengikatan. Setelah seluruh dokumen terkait pengikatan telah terkumpul, maka kemudian diserahkan ke notaris untuk diperiksa apakah dokumen-dokumen tersebut sudah lengkap. Setelah notaris memeriksanya, maka notaris akan memberitahukan kepada bank bahwa semua dokumen sudah lengkap dan bersih (dalam artian tidak bermasalah).

Setelahitu, bank mengundang para pihak, baik debitur dan notaris sebelum pencairan kredit untuk keperluan penandatanganan akta dan dokumen- dokumen lainnya yang dianggap perlu untuk ditandatangani. Setelah semuanya ditandatangani dan dinyatakan lengkap, maka dilakukanlah proses lanjutan seperti pembebanan penjaminan terhadap barang jaminan. Dalam proses inilah covernote biasanya diminta oleh kreditor maupun debitor untuk keperluan pencairan kredit yang dimaksud.

Menurut penulis, Notaris haruslah tetap memperhatikan kepentingan para pihak. Notaris memberikan pernyataan dalam bentuk tertulis mengenai proses dari dokumen kelengkapan pencairan kredit yang dituangkan dalam covernote, maka notaris bertanggungjawab atas isi atau penyataan dalam covernote tersebut. Notaris yang menyampaikan informasi tidak benar dalam covernote, maka notaris dapat dimintai pertanggungjawaban hukum atas pernyataannya itu. Oleh sebab itu, maka notaris juga perlu untuk berhati-hati dalam menerbitkan covernote, ia harus menyampikan informasi yang benar kepada pihakpihak terkait mengenai proses dokumen yang diurusnya.

Mengenai tanggung jawab notaris terhadap covernote yang diterbitkannya, menurut penulis dapat dikategorikan sebagai tanggung jawab secara personal atau pribadi. Dikaitkan kembali dengan teori tanggung jawab menurut Kranenburg dan Vegting dimana dikemukakan ada dua teori pertanggungjawaban, yaitu teori fautes personalles dan teorifautes de service. ${ }^{11}$ Teori fautes personalles merupakan teori yang tepat untuk digunakan menilai pertanggungjawaban notaris terhadap covernote yang diterbitkannya. Teori beban tanggung jawab ini ditujukan pada manusia selaku pribadi. Menurut penulis, beban tanggung jawab notaris terhadap covernote yang dikeluarkannya ditujukan kepada dirinya selaku manusia pribadi

11 Ridwan H.R., 2006, Hukum Administrasi Negara, Raja Grafindo Persada, Jakarta, hlm. 335-337. Menurut Kranenburg dan Vegting ada dua teori tanggung jawab, yaitu: Pertama, teori fautes personalles, yaitu teori yang menyatakan bahwa kerugian terhadap pihak ketiga dibebankan kepada pejabat yang karena tindakannya itu telah menimbulkan kerugian. Dalam teori ini beban tanggung jawab ditujukan pada manusia selaku pribadi. Kedua, teori fautes de services, yaitu teori yang menyatakan bahwa kerugian terhadap pihak ketiga dibebankan pada instansi dari pejabat yang bersangkutan. Menurut teori ini tanggung jawab dibebankan kepada jabatan. Dalam penerapannya, kerugian yang timbul itu disesuaikan pula apakah kesalahan yang dilakukan itu merupakan kesalahan berat atau kesalahan ringan, dimana berat dan ringannya suatu kesalahan berimplikasi pada tanggung jawab yang harus ditanggung. 
yang memikul tanggung jawab jabatan. Terlebih lagi bahwa jabatan notaris akan dipikul selama masa jabatannya berlangsung dan tidak dapat dialihkan kepada orang/pihak lain.

Covernote diterbitkan oleh penjabat notaris dalam menjalankan jabatannya sebagai notaris. Untuk itu, maka tanggung jawab terhadap penerbitan covernote tersebut harus dipikul oleh si penjabat notaris itu sendiri. Konsep ini akan berbeda dengan pejabat pada lingkungan perusahaan atau pemerintahan dimana beban tanggung jawab dapat dialihkan ke instansi sebagaimana teori fautes de services. Oleh karena notaris merupakan pejabat publik yang tidak memiliki instansi, maka beban tanggung jawab atas pelaksanaan jabatannya dipikul oleh si penjabat notaris, baik dalam kapasitasnya sebagai notaris maupun sebagai manusia pribadi.

Notaris bertanggungjawab langsung terhadap isi dan informasi yang disampaikan dalam covernote. Informasi Notaris yang disampaikan dalam covernote, apabila menyebabkan kerugian terhadap suatu pihak, maka notaris dapat dimintai pertanggungjawaban hukum. Dalam konteks ini, pertanggungjawaban hukum yang dapat bebankan kepada notaris adalah pertanggungjawaban pidana dan perdata. Secara pidana, tanggung jawab yang dipikul oleh notaris terhadap covernote yang diterbitkannya adalah dalam hal menyampaikan informasi yang tidak benar dan bahkan dapat diduga melakukan penipuan. Kemudian secara perdata, Pasal 1365 KUHPerdata diatur.

"Tiap perbuatan melanggar hukum yang membawa kerugian pada orang lain, mewajibkan orang yang karena salahnya menerbitkan kerugian itu, mengganti kerugian tersebut" 12

Pasal 1366 KUHPerdata lebih lanjut mengatur.

"Setiap orang bertanggung jawab tidak saja untuk kerugian yang disebabkan karena perbuatannya, tetapi juga untuk kerugian yang disebabkan karena kelalaian atau kurang hati-hatinya"13

Merujuk pada Pasal 1366 ini, maka perbuatan notaris tersebut, baik disengaja maupun tidak disengaja, ia harus tetap bertanggungjawab atas kerugian yang diderita oleh kreditor. Penggunaan covernote dalam perjanjian kredit juga tidak bisa dilepaskan dari peran bank itu sendiri. Bank dalam praktiknya seringkali karena alasan persaingan bisnis dalam mendapatkan calon nasabah/debitur bertindak kurang hati-hati, karena kekhawatiran larinya nasabah/debitor ke bank lain. Seharusnya bank dalam memberikan layanan kredit tetap harus menempuh cara-cara yang menunjang prinsip kehati-hatian bank untuk memastikan bahwa kredit yang akan disalurkan tidak akan bermasalah. Hal ini sesuai dengan ketentuan Pasal 29 angka (3) UndangUndang Perbankan yang menyatakan bahwa dalam memberikan kredit atau pembiayaan berdasarkan prinsip syariah dan melakukan kegiatan usaha lainnya, bank wajib menempuh cara-cara yang tidak merugikan bank dan kepentingan nasabah yang mempercayakan dananya kepada bank.

\section{Implikasi Hukum Terhadap Pencairan Kredit Perbankan Atas Dasar Covernote Notaris}

Bank memegang peranan yang sangat penting selaku lembaga keuangan yang membantu pemerintah untuk membantu pemerintah mencapai kemakmuran. Dengan demikian disadari bahwa kredit mempunyai peranan yang sangat penting dalam perekonomian negara. Fungsi kredit di dalam kehidupan perekonomian secara garis besar adalah sebagai berikut: Pertama, untuk meningkatkan daya guna uang. Dengan adanya kredit akan dapat meningkatkan daya guna uang. Maksudnya adalah jika uang hanya disimpan saja tidak akan menghasilkan sesuatu yang berguna. Sebaliknya 
apabila uang tersebut dipergunakan sebagai kredit maka akan berguna untuk menghasilkan barang atau jasa oleh si penerima kredit.

Terdapat dua cara yang dapat dilakukan oleh pemilik uang terhadap uangnya yaitu ${ }^{14}$ : 1) Pemilik uang/modal dapat secara langung meminjamkan uang/modalnya kepada para pengusaha yang memerlukannya untuk meningkatkan produksi atau usahanya; 2) Pemilik uang/modal dapat menyimpan uang/modalnya pada lembaga-lembaga keuangan. Uang/modal yang disimpan tersebut akan disalurkan kembali oleh lembaga-lembaga keuangan tersebut sebagai pinjaman bagi perusahaan-perusahaan yang memerlukannya untuk meningkatkan produksi atau usahanya.

Kedua, untuk meningkatkan peredaran dan lalu lintas uang. Kredit yang disalurkan oleh bank dapat menciptakan peredaran uang giral dan uang kartal. Kredit yang disalurkan melalui rekening giro dapat menciptakan pembayaran baru seperti cek, bilyar giro dan wesel sehingga apabila pembayaranpembayaran dilakukan dengan cek, bilyet giro dan wesel maka akan dapat meningkatkan peredaran uang giral. Kredit perbankan yang ditarik secara tunai dapat meningkatkan peredaran uang kartal. ${ }^{15}$ Oleh karena itu, dengan kredit akan menciptakan suatu kegairahan berusaha sehingga penggunaan uang akan bertambah baik secara kualitatif. ${ }^{16}$

Ketiga, kredit yang diberikan oleh bank akan digunakan oleh si penerima kredit (pengusaha) untuk mengolah barang yang tidak berguna menjadi barang yang berguna. ${ }^{17}$ Dengan adanya bantuan kredit ini, maka pengusaha dapat meningkatkan daya guna barang, yang juga akan meningkatkan harga jual barang tersebut. Keempat, untuk meningkatkan peredaran barang. Kredit dapat meningkatkan peredaran barang, baik melalui penjualan secara kredit maupun dengan membeli barang-barang di satu tempat dan menjualnya ditempat lain. ${ }^{18}$ Dengan adanya kredit maka akan meningkatkan jumlah barang yang beredar di masyarakat. Selain itu juga dapat pula meningkatkan manfaat suatu barang.

Kelima, sebagai alat stabilitas ekonomi. Dengan memberikan kredit dapat dikatakan sebagai stabilitas ekonomi karena dengan adanya kredit yang diberikan oleh bank, maka akan semakin meningkat jumlah barang di masyarakat. Sehingga masyarakat dapat terpenuhi kebutuhannya. Selain itu kredit dapat membantu dalam mengekspor barang ke dalam atau luar negeri. ${ }^{19}$ Keenam, untuk meningkatkan kegairahan berusaha Setiap orang akan selalu berusaha untuk meningkatkan usahanya. Namun, terkadang dibatasi pada kemampuan permodalan. Bantuan kredit dari bank akan dapat mengatasi hal tersebut. Sehingga para pengusaha dapat meningkatkan usahanya. ${ }^{20}$

Ketujuh, untuk meningkatkan pemerataan pendapatan. Dengan bantuan kredit dari bank kepada pengusaha, maka akan semakin banyak lapangan kerja baru yang berarti akan semakin banyak tenaga kerja yang tertampung pada lapangan kerja tersebut dan pemerataan pendapatan akan tercapai. ${ }^{21}$ Kedelapan, untuk meningkatkan hubungan internasional. Pinjaman internasional akan meningkatkan kebutuhan antara si penerima kredit dengan pemberi kredit. Pemberian kredit oleh negara lain akan meningkatkan kerja sama dibidang lain, sehingga dapat pula tercipta perdamain dunia. ${ }^{22}$

Sebelum debitur mendapatkan kredit dari kreditur (bank), terdapat beberapa tahapan dalam proses penilaian mulai dari pengajuan proposal kredit dan dokumen-dokumen yang dibutuhkan, pemeriksaan keaslian dokumen tersebut, analisis kredit sampai dengan kredit dicairkan. Tahapan

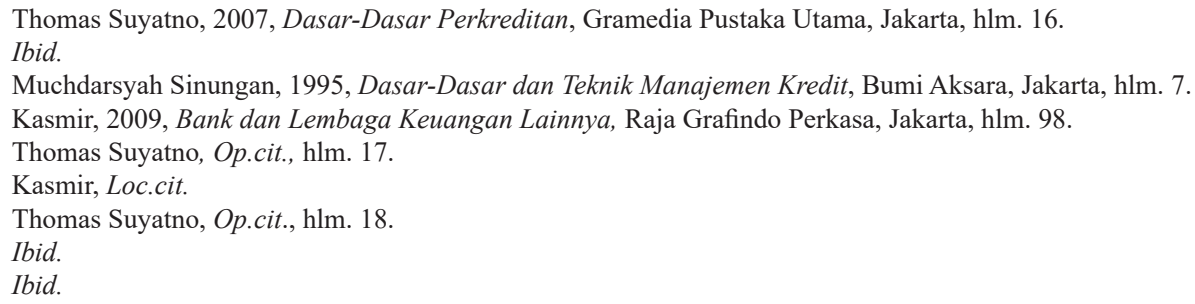


dalam pemberian kredit ini diperlukan untuk memastikan kelayakan suatu kredit. Kelayakan suatu kredit, pada setiap tahap selalu dilakukan suatu penilaian yang mendalam. Penilaian yang di dalamnya terdapat kekurangan, maka pihak bank bisa meminta kembali ke nasabah untuk melengkapi kekurangan tersebut atau bahkan permohonan kredit tersebut langsung ditolak. Tahapan dalam pemberian kredit dapat penulis uraikan sebagai berikut: ${ }^{23}$ Pertama, penilaian berkas pemohon (calon debitur); Kedua, verifikasi data, yakni: a) On the Spot (OTS) Checking; b) Bank Checking; c) Trade Checking atau Personal Checking untuk Kredit Konsumsi; Ketiga, penilaian dan analisis kebutuhan kredit; Keempat, keputusan kredit; Kelima, penandatanganan perjanjian kredit dan perjanjian-perjanjian lainnya; Keenam, realisasi kredit.

Dari pemaparan di atas tampak bahwa notaris sangat berperan dalam penyaluran kredit perbankan, yakni membuat segala akta yang diperlukan dan memproses pembebanan terhadap barang jaminan. Pada proses inilah biasanya diterbitkan covernote sebagai jaminan kepada bank bahwa barang jaminan dalam proses pembebanan. Covernote dibutuhkan oleh pihak bank untuk segera merealisasikan kredit yang akan disalurkannya kepada nasabah.

Covernote atau surat keterangan dari notaris sangat membantu pihak bank dalam hal pemberian kredit karena covernote merupakan pernyataan dari notaris yang di dalamnya menjelaskan proses, progress dan kendala dari perbuatan hukum yang dikerjakan oleh notaris. Hal ini sekaligus menjadi dasar atau pegangan pihak bank untuk merealisasikan secepatnya kredit yang dimohonkan. Hal ini berarti pihak bank memberikan kepercayaan yang cukup tinggi terhadap notaris sebagai mitra bank dalam melakukan perbuatan hukum dengan masyarakat.

Begitu besar dan tingginya kepercayaan yang diberikan kepada notaris sebagai pejabat umum menunjukkan bahwa jabatan notaris adalah jabatan mulia. Untuk itu, maka dalam Pasal 16 ayat (1) angka 1 UUJN mengatur bahwa notaris wajib bertindak amanah, jujur, saksama, mandiri, tidak berpihak, dan menjaga kepentingan pihak yang terkait dalam perbuatan hukum. Hal ini cukup jelas memperlihatkan bahwa begitu besar tanggung jawab notaris dalam melaksanakan fungsi-fungsinya. Selain itu, notaris juga mengemban tanggung jawab moral yang cukup besar dalam melaksanakan kewenangan-kewenangan yang diberikan oleh undang-undang sehingga jika notaris melakukan suatu tindak pidana ataupun perbuatan yang tidak sepantasnya, maka akan mecederai jabatan notaris secara keseluruhan.

Kelalaian notaris dalam menerbitkan covernote yang isinya mengandung pernyataan atau informasi yang tidak benar menyebabkan ia harus memikul tanggung jawab hukum atas perbuatannya, yakni tanggung jawab pidana maupun tanggung jawab perdata. Bahkan dalam konteks ini, notaris memikul tanggung jawab moral terhadap jabatan yang diembannya. Sebagaimana telah diuraikan sebelumnya bahwa jika seorang notaris melanggar suatu ketentuan hukum terkait dengan pelaksanaan jabatannya, maka UUJN telah menentukan sanksisanksi yang dapat dikenakan terhadap notaris, yakni berupa teguran lisan, teguran tertulis, pemberhentian sementara, pemberhentian dengan hormat, atau pemberhentiang dengan tidak hormat.

Kelalaian notaris dalam menerbitkan covernote untuk keperluan realisasi kredit perbankan adalah tindakan yang tidak sesuai dengan ketentuan peraturan perundang-undangan yang berlaku. Tindakan notaris ini dapat menurunkan tingkat kepercayaan masyarakat atas jabatan notaris. Dengan kata lain, tindakan yang dilakukan oleh notaris pada kasus ini dapat merusak dan merendahkan kehormatan dan martabat jabatan

\footnotetext{
23 Disarikan dari penulusuran penulis lewat internet dengan bersumber dari UPACAYA, "Proses Pemberian Kredit", http://www.upacaya.com/ proses-pemberian-kredit/, diakses 18 April 2018; lihat juga Ilmu Ekonomi ID, "Prosedur Pemberian Kredit Bank", http://www.ilmu-ekonomiid.com/2017/05/prosedur-pemberian-kredit-bank.html, diakses 18 April 2018.
} 
notaris.

Dalam penyaluran kredit, bank harus berpegang teguh pada prinsip kehati-hatian sebagaimana diamanahkan oleh Undang-Undang Nomor 10 Tahun 1998 tentang Perubahan Atas Undang-Undang Nomor 7 Tahun 1992 Tentang Perbankan (selanjutnya disebut UU Perbankan). Setiap pemberian kredit, baik secara langsung maupun tidak langsung akan berpengaruh terhadap bank. Oleh karena itu sebelum pemberian kredit disetujui perlu dilakukan analisis terhadap permohonan kredit tersebut. Hal ini sesuai dengan ketentuan dalam Pasal 2 Undang-Undang Perbankan yang menyatakan bahwa perbankan Indonesia dalam melaksanakan usahanya berasaskan demokrasi ekonomi dengan menggunakan prinsip kehati-hatian. Penerapan prinsip kehati-hatian bertujuan agar bank tetap dalam kondisi sehat, menjaga kepercayaan masyarakat kepada bank dan dapat memberikan manfaat secara ekonomi kepada masyarakat.

Salah satu aspek penerapan prinsip kehatihatian dalam pemberian kredit, yakni terkait dengan penilaian jaminan yang akan diberikan oleh calon nasabah debitur. Bank harus menilai beberapa kriteria jaminan yang baik, antara lain terkait dengan aspek yuridis, ekonomis, dan sosial. Adapun penilaian aspek yuridis dilaksanakan dengan melakukan penelitian terkait dengan keabsahan dan kebenaran dokumen bukti kepemilikan barang yang akan dijadikan jaminan kredit.

Realitas yang terbangun saat ini bahwa kehadiran notaris sebagai mitra bank dalam menyalurkan kredit dapat mempermudah kerja bank terkait verifikasi dokumen-dokumen yang diajukan nasabah. Dalam hal ini, notaris melaksanakan sebagian peran dari pihak bank, misalnya dalam memverifikasi dokumen agunan sehingga pada praktiknya, bank tidak lagi melakukan verifikasi terhadap keabsahan dokumen agunan tersebut. Pihak bank hanya memastikan ada atau tidaknya barang yang akan dijaminkan tersebut sehingga pihak bank tidak lagi mencari tahu keabsahan dari barang jaminan tersebut. Untuk memverifikasi keabsahan barang jaminan tersebut, notaris yang melakukannya dengan cara melakukan pengecekan kepada instansi yang terkait. Tanah yang dijaminkan sebagai barang jaminan, maka bank hanya melakukan survey lokasi untuk melihat keberadaan tanah yang dimaksud, sedangkan untuk keabsahan sertifikat tanah tersebut dilakukan oleh notaris dengan cara melakukan pengecekan di Kantor Pertanahan setempat.

Keberadaan covernote saat ini menjadi eksis dan urgen dimana covernote yang diterbitkan oleh notaris akan memberikan keterangan sehingga membuat kreditor/bank menjadi yakin bahwa sekalipun bank merealisasikan kredit yang dimohonkan oleh debitor yang agunannya masih dalam proses hukum, nantinya tetap akan didapatkan dan dikuasai oleh pihak bank. Apalagi yang melakukan proses tersebut adalah notaris yang notabene adalah jabatan yang sangat dipercaya. Namun demikian, covernote bukanlah anggunan, sedangkan syarat kredit perbankan mensyaratkan harus adanya anggunan yang diberikan oleh debitor sebagai penerapan prinsip kehati-hatian oleh bank.

Kondisi yang dipaparkan di atas memperlihatkan bahwa dalam praktiknya, notaris mendapatkan kepercayaan yang tinggi dari masyarakat dan lembaga keuangan. Segala pengurusan terkait mengenai perbuatan hukum masyarakat dan lembaga keuangan dipercayakan kepada notaris. Untuk itu penulis menekankan kembali bahwa notaris dalam menjalankan fungsinya harus memperhatikan dan menjaga nama baik serta keluhuran jabatan notaris.

Seorang notaris haruslah menjaga marwah dan martabat jabatannya. Untuk itu, maka notaris dalam menjalankan fungsi-fungsinya harus pula senantiasa memegang prinsip kehati-hatian agar tidak terjerumus pada perbuatan-perbuatan yang melawan hukum. Notaris sepatutnya melaksanakan jabatannya sesuai dengen ketentuan hukum yang berlaku dan dituntut mawas diri oleh karena berbagai karakter orang yang berhadapan dengannya. Tidak ada yang bisa menjamin bahwa setiap orang (klien) yang datang kepadanya adalah orang baik dan memiliki itikad baik, terkadang 
yang datang kepadanya justru orang yang ingin memanfaatkan keberadaan notaris dengan tujuan mendapatkan keuntungan yang besar bagi dirinya sendiri sehingga menimbulkan kerugian pada pihak lainnya. Kedudukan notaris dalam menjalankan fungsinya dituntut untuk lebih aktif lagi, khususnya dalam memverifikasi data-data atau dokumendokumen yang diperhadapkan kepadanya.

\section{Kesimpulan}

Berdasarkan hasil penelitian ini, dapat disimpulkan bahwa: Pertama, tanggung jawab notaris dalam menerbitkan covernote terhadap pencairan kredit perbankan adalah notaris bertanggung jawab penuh atas isi dari covernote yang diterbitkannya. Covernote yang diterbitkan oleh notaris menjadi pegangan dan jaminan bagi kreditor bahwa dokumen-dokumen yang terkait dengan realisasi kredit perbankan sedang dalam pengurusan oleh notaris sehingga bank atas dasar covernote tersebut dapat merealisasikan kredit yang dimohonkan oleh debitor. Ketidaksesuaian yang terjadi antara pernyataan dalam covernote dengan realitasnya di lapangan, notaris harus bertanggung jawab, baik secara pidana ataupun perdata dan bahkan bertanggung jawab secara moral.

Kedua, implikasi hukum terhadap pencairan kredit perbankan atas dasar covernote notaris adalah berimplikasi pada eksistensi jabatan notaris itu sendiri. Jabatan notaris adalah profesi yang diberikan kepercayaan besar dan tinggi oleh masyarakat sehingga apa yang dituangkannya dalam produk hukumnya ataupun pada keterangaketerangannya dapat dianggap sebagai sesuatu yang benar. Jadi, ketika terdapat pernyataan notaris yang tidak sesuai dengan keadaan yang sebernanya, maka akan berdampak pada tercederainya profesi notaris itu sendiri.

\section{DAFTAR PUSTAKA}

\section{A. Buku}

Adjie, Habib, 2012, Bernas-Bernas Pemikiran di Bidang Notaris dan PPAT, Mandar Maju, Bandung.

Anshori, Abdul Ghofur., 2009, Lembaga Kenotariatan Indonesia: Perspektif Hukum dan Etika, UII Press, Yogyakarta.

Bruggink, JJH., 1996, Refleksi tentang Hukum, (diterjemahkan: oleh Arief Sidharta), Citra Aditya Bakti, Bandung.

H.R., Ridwan, 2006, Hukum Administrasi Negara, Raja Grafindo Persada, Jakarta.

Kansil, C.S.T., 1989, Pengantar Ilmu Hukum dan Tata Hukum Indonesia, Balai Pustaka, Jakarta.

Kasmir, 2009, Bank dan Lembaga Keuangan Lainnya, Raja Grafindo Perkasa, Jakarta.

Kie, Tan Thong, 2000, Buku I Studi Notariat (Serba-Serbi Praktek Notaris), Ichtiar Baru Van Hoeve, Jakarta.
Sinungan, Muchdarsyah, 1995, Dasar-Dasar dan Teknik Manajemen Kredit, Bumi Aksara, Jakarta.

Soegondo, R. 1993, Hukum Notariat di Indonesia Suatu Penjelasan, Raja Grafindo Persada, Jakarta.

Subekti, 1991, Pokok-Pokok Hukum Perdata, Intermasa, Jakarta.

Suyatno, Thomas, 2007, Dasar-Dasar Perkreditan, Cetakan Keempat, Gramedia Pustaka Utama, Jakarta.

\section{B. Artikel Jurnal}

Rachmiyani, Dewi, et al., "Covernote Notaris Dalam Perjanjian Kredit Dalam Perspektif Hukum Jaminan", Acta Diurnal (Jurnal Ilmu Hukum Kenotariatan), Vol. 1, No. 1, Desember 2017.

Sanjaya, I Dewa Made Dwi, “Tanggung Jawab Hukum Notaris Terhadap Penerbitan 
Covernote Dalam Pemberian Kredit", Riau Ilmu Ekonomi ID, "Prosedur Pemberian Kredit Law Journal, Vol. 1, No. 2, November 2017. Bank", http://www.ilmu-ekonomi-id.

\section{Makalah}

Setiawan, Wawan, Kedudukan dan Keberadaan Pejabat Umum serta PPAT dibandingkan dengan Kedudukan Pejabat Tata Usaha Negara Menurut Sistem Hukum Nasional, Pengurus Pusat Pejabat Pembuat Akta Tanah, Jakarta, 2 Juli 2011.

\section{Internet}

UPACAYA, "Proses Pemberian Kredit", http:// www.upacaya.com/proses-pemberiankredit/, diakses 18 April 2018. com/2017/05/prosedur-pemberian-kreditbank.html, diakses 18 April 2018.

\section{E. Peraturan Perundang-undangan}

Kitab Undang-Undang Hukum Perdata.

Undang-Undang Nomor 2 Tahun 2014 tentang Perubahan atas Undang-Undang Nomor 30 Tahun 2004 tentang Jabatan Notaris (Lembaran Negara Republik Indonesia Tahun 2014 Nomor 3, Tambahan Lembaran Negara Republik Indonesia Nomor 5491). 